\title{
Reproduction of Megapitaria squalida (Bivalvia: Veneridae) in the Southeast Gulf of California, Mexico
}

\author{
Ernesto Álvarez-Dagnino, Apolinar Santamaría-Miranda, Manuel García-Ulloa \\ \& Andrés M. Góngora-Gómez* \\ Instituto Politécnico Nacional, Centro Interdisciplinario de Investigación para el Desarrollo Integral Regional \\ (CIIDIR-Unidad Sinaloa), Departamento de Acuacultura, Guasave, Sinaloa, México; ernestinomx@hotmail.com, \\ asantama@ipn.mx, turbotuag@hotmail.com, gogam69@hotmail.com*
}

Received 17-XI-2016. Corrected 20-III-2017. Accepted 19-IV-2017.

\begin{abstract}
Bivalves reproductive cycle varies according to the particular environmental conditions where they are found, and these reproductive details represent basic information for their capture, management and conservation strategies. With this objective, the reproductive cycle of the clam Megapitaria squalida, inhabiting the Southeast of the Gulf of California (Altata Bay, Sinaloa, Mexico), was studied using histology and changes in the number and size of oocytes, from June 2013 to June 2014. Histological analysis of the gonads showed spawning activity throughout the year, with two peaks. The first was registered in October and it was accompanied by the highest decrease of weight; the second was in February with the highest percentage of spawning population; besides, a resting period was observed in December. The sex-ratio (female:male) of the clam population was 1.08:1 $\left(\chi^{2}=5.72\right.$, d.f. $\left.=1, \mathrm{P}<0.05\right)$. Mean oocyte size and number were different $(\mathrm{P}<0.05)$ among all sampling months and fluctuated from $34.6 \pm 5.8 \mu \mathrm{m}$ in June 2014, to $41.9 \pm 6.8 \mu \mathrm{m}$ in February 2014, and from $443.8 \pm$ 424.5 in February 2014, to $1214.4 \pm 267.6$ counted in April, respectively. With these results we suggest a protection season from October to November, when the most intense release of gametes occur in this population. Rev. Biol. Trop. 65 (3): 881-889. Epub 2017 September 01.
\end{abstract}

Key words: gonadic index, Megapitaria squalida, oocyte development, spawning season, capture management, conservation.

Studies on reproduction of commercial bivalves are essential to come up with management strategies for their conservation and sustainable exploitation. The clam Megapitaria squalida (Sowerby, 1835) commonly known as "squalid callista" or "callista clam", is distributed from the North of California (Scammon's Lagoon) along the Pacific coast, to Mancora, Peru, and in both coasts of the Gulf of California. It is a filter-feeder that lives burrowed in sandy sediments, from intertidal areas to depths of about $160 \mathrm{~m}$ (Keen, 1971), and its shell can reach a length, height and width of 120, 97 and $68 \mathrm{~mm}$, respectively (Singh, Vélez, \& Fajardo, 1991).

Although this species is considered as a resource of low commercial value, it is particularly appreciated in Mexico, and represents an important alternative fishery in the Gulf of California and the Pacific coast of Mexico. Commonly, clams are captured for personal consumption or sold in local and regional markets. M. squalida is harvested by free or scuba diving until a depth of 10 $\mathrm{m}$, and is also hand collected in intertidal sand flats (Scheweers, Wolff, Koch, \& SinselDuarte, 2006). There are some reports about its exploitation in Bahia Concepción (CastroOrtíz, Tripp-Quezada, \& Anguas-Velez, 1992) and different coastal locations of the Gulf of California, Mexico (Baqueiro-Cárdenas, Masso, \& Guajardo, 1982). However, LópezRocha et al. (2010) stated that the callista clam fishery in some places of Baja California Sur 
reached its maximum level of exploitation and overfishing. Besides, Vázquez-Hurtado, Manzano-Sarabia and Ortega-Rubio, (2011) pointed out that anomalous conditions of sea surface temperature have exerted negative effects on clam landings.

Latest production statistics in 2014 report a total volume of 4319 tons of which $99.7 \%$ were registered from Northwest Mexico, and the rest for the state of Sinaloa, in the Southeastern part of the Gulf of California (SAGARPA, 2015). In the specific case of Sinaloa state, the annual average catch of $M$. squalida was around 53 tons in 2008, with a collapse to 12 tons in 2014; that pointed out an overexploitation of this resource. Since official estimations for last two decades refer to captures all year round in this state, it is possible to assume a lack of a close season, as a consequence of the absence of biological studies on its reproductive cycle. The overexploitation of the callista clam has led to regional fishery authorities (ISAPESCA, Instituto Sinaloense de Acuacultura y Pesca) to impel a research project on different biological aspects of the species. Part of this project was focused to increase knowledge on this species reproductive cycle, for a better management and conservation of this clam in Sinaloa state (Ruíz-García et al., 2013).

Nowadays, the reproductive cycle of the callista clam has been described predominantly for the populations from Northwestern Mexico (Baqueiro \& Stuardo, 1977; Villalejo-Fuerte, García-Melgar, Ochoa-Báez, \& García-Gasca, 1996; Quiñones-Arreola, 2003; Arellano-Martínez, Quiñones-Arreola, Ceballos-Vázquez, \& Villalejo-Fuerte, 2006; Schweers et al., 2006), but there is no information for the Southeastern clam communities of the Gulf of California. The reproductive cycle of bivalves varies with the geographic location, according to the particular environmental conditions in each location, mainly water temperature and food availability (Cruz \& Villalobos, 1993; Rodríguez et al., 1993; Vázquez-Hurtado et al., 2011). Therefore, the aim of this study was to provide information on the reproductive cycle of M. squalida in the Southeast coast of the
Gulf of California and to propose management practices for its sustainable conservation.

\section{MATERIALS AND METHODS}

A total of 210 specimens of $M$. squalida were hand collected ( $\mathrm{N}=30$ bimonthly) on a sandy bottom (1.5 m depth) in Altata Bay, Sinaloa, Mexico $\left(24^{\circ} 20^{\prime} 55^{\prime \prime}\right.$ - 24⒍ $62^{\prime} 67^{\prime \prime} \mathrm{N}$ \& $\left.107^{\circ} 20^{\prime} 25-107^{\circ} 92^{\prime} 36^{\prime \prime} \mathrm{W}\right)$, and examined for histological studies from June 2013 to June 2014. The climate of this region is warm (17.2 to $32.2{ }^{\circ} \mathrm{C}$, mean minimum and maximum temperatures; Ruíz, Medina, Macías, Silva, \& Díaz, 2005), with a rainy season from June to September-October, and a dry season from November to May (Gaxiola-Castro, 2003).

Environmental parameters: To evaluate the possible influence of environmental factors on the reproductive cycle of $M$. squalida, water parameters were measured at each sampling. Seawater temperature $\left({ }^{\circ} \mathrm{C}\right)$ and salinity were monitored with an oxymeter and a refractometer, respectively. Water samples were collected from the bottom ( $0.90 \mathrm{~m}$ deep) for determination of chlorophyll $a(\mathrm{Cl} a)$. Pigment analyses were carried out after water filtration with Whatman GF/F glass filters $(0.7 \mu \mathrm{m}$ pore size $)$ using Millipore vacuum filtration. The $\mathrm{Cl} a$ concentration $\left(\mathrm{mg} / \mathrm{m}^{3}\right)$ was determined by standard spectrophotometric methods (Strickland $\&$ Parsons, 1972). Concentrations of Cla were calculated using the thrichromatic equations of Jeffrey and Humphrey (1975).

Biometric analysis: The shell length (SL = line straight distance from umbo to ventral margin of the shell, $\mathrm{mm}$ ) and weight (g) of each clam were measured in situ with a caliper $(0.01 \mathrm{~mm})$ and a portable balance $(0.0 \mathrm{~g})$, respectively. The changes in weight could be related to somatic growth and/or variations in the size of the specimens between successive samples. Thus, the variations of weight was estimated for a standard individual of 67.95 $\mathrm{mm}$ long, the mean size of the population, for which the changes in weight must be related 
with the development of the gonads. For the estimation of the bimonthly weights of the standard individual, regression lines for the weight-length relationship were calculated, after a logarithmic transformation of Ricker's function $\mathrm{W}=\mathrm{aL}^{\mathrm{b}}$ (Ricker, 1975), where $\mathrm{W}$ is the weight, $\mathrm{L}$ the length, a the ordinate at origin and $b$ the slope. The gonadic index was obtained according to the stages $1=$ undifferentiated and resting, 2 = development, and $3=$ ripe, and applying the formula $\mathrm{GI}=\left(\mathrm{n}_{1}+\right.$ $\left.3 \mathrm{n}_{2}+2 \mathrm{n}_{3}\right) / \mathrm{Nt}$, where $\mathrm{n}=$ number of organisms in stages 1, 2 and 3, and $\mathrm{Nt}=$ total organisms (Arellano-Martínez et al., 2006).

Histological preparations: To determine the gonad development, the visceral mass of each clam (gonad included) was dissected and fixed in Davison's solution for 24 hours. A conventional histological technique (Humason, 1979) comprising dehydration through a sequence of alcohol solutions of increasing concentration followed by clearing with Hemo$\mathrm{De}^{\circledR}$ and embedding in Paraplast-Xtra ${ }^{\circledR}$ was used. Sections of tissue that were $4 \mu \mathrm{m}$ thick were cut, stained with haematoxylin-eosin and examined under a light microscope. Each clam was analyzed for gonadal development, from one to five arbitrary gonad stages, previously established for this species: undifferentiated, developing, ripe, spawning and spent (Villalejo-Fuerte, Arellano-Martínez, CeballosVázquez, \& García-Domínguez, 2000). Since M. squalida does not exhibit sex dimorphism, clams were sexed through histological analysis. Sex ratios were analyzed each two months testing the null hypothesis of a 1:1 sex ratio, using a chi-square test ( $\alpha=0.05$; Zar, 1996). The oocyte diameter was determined bimonthly from digitalized images of histological sections by means of a LEICA DM4000 B LED microscope equipped with a camera LEICA DFC450 $\mathrm{C}$ using the imaging software LAS version 4.6.1. All oocytes within the visual microscopical space $\left(5.35 \mathrm{~mm}^{2}\right)$ from five slides per sampled month were measured. Only oocytes showing a nucleolus were measured, assuming that this structure is located at the cell center (Laruelle, Guillou, \& Paulet, 1994).

One-way ANOVA was employed to examine the sizes and weights of female and male M. squalida at each sampling; when statistical significances were detected, a posteriori multiple comparison tests (Tukey's test) were conducted. One-way ANOVA was also used to evaluate the variations in number and diameter of oocytes. A Pearson's correlation analysis was applied to investigate the relationship among the mean oocyte diameter, water temperature, $\mathrm{Cl} a$ concentrations and growth ( $\mathrm{SH}$, $\mathrm{mm}$; TW, g) of the callista clam. The differences in bimonthly sex ratios were tested using Chi-square tests $\left(\chi^{2}\right)$ with Yates' continuity correction (Zar, 1996). All statistical analyses were performed using STATISTICA for Windows (ver. 6.0, Statsoft). A significance level of $\alpha=0.05$ was set in all tests.

\section{RESULTS}

Environmental parameters: The maximum seawater temperatures at the collecting site were registered in June and August (31.0 $\left.\pm 0.0^{\circ} \mathrm{C}\right)$ and the minimum $\left(20.0 \pm 0.8^{\circ} \mathrm{C}\right)$ in December, January and February. The mean concentrations of $\mathrm{Cl} a$, POM and TSS were $4.25 \pm 0.42 \mathrm{mg} / \mathrm{m}^{3}, 14.78 \pm 0.52 \mathrm{mg} / \mathrm{L}$ and $39.61 \pm 0.52 \mathrm{mg} / \mathrm{L}$, respectively. There were no significant correlation $(\mathrm{P}<0.05)$ between temperature with $\mathrm{Cl} a(\mathrm{r}=0.44, \mathrm{P}=0.11), \mathrm{POM}(\mathrm{r}$ $=-0.1, P=0.72)$ and TSS $(r=0.001, P=0.99)$. The monthly POM values were positively correlated with TSS $(\mathrm{r}=0.80, \mathrm{P}=0.0006)$. The mean transparency and depth values were 0.97 $\pm 0.3 \mathrm{~m}$. The maximum transparency and depth were obtained in March $(1.5 \pm 0.1 \mathrm{~m})$ and the lowest $(0.5 \pm 0.1 \mathrm{~m})$ in February. The monthly fluctuations of dissolved oxygen, salinity and $\mathrm{pH}$, averaged $4.46 \pm 0.09 \mathrm{mg} / \mathrm{L}, 33.38 \pm 0.14$ ups and $7.6 \pm 0.19 \mathrm{upH}$, respectively.

Biometrics: The mean length and weight of M. squalida varied $(\mathrm{P}<0.05)$ among samplings and were included in table 1 . 
TABLE 1

Length (mm) and weight (g) of the callista clam $M$. squalida collected in Altata Bay,

Sinaloa, Mexico, from June 2013 to June 2014

\begin{tabular}{lcc} 
& Length $(\mathrm{mm})$ & Weight $(\mathrm{g})$ \\
June 2013 & $66.69 \pm 3.66^{\mathrm{c}}$ & $93.0 \pm 15.6^{\mathrm{d}}$ \\
August & $68.50 \pm 4.46^{\mathrm{c}}$ & $85.5 \pm 17.2^{\mathrm{bc}}$ \\
October & $68.93 \pm 3.88^{\mathrm{c}}$ & $85.5 \pm 16.9^{\mathrm{bc}}$ \\
December & $62.38 \pm 3.84^{\mathrm{a}}$ & $67.9 \pm 13.0^{\mathrm{a}}$ \\
Febraury 2014 & $66.86 \pm 3.55^{\mathrm{b}}$ & $81.7 \pm 11.2^{\mathrm{b}}$ \\
April & $69.97 \pm 3.01^{\mathrm{bc}}$ & $89.9 \pm 13.9^{\mathrm{cd}}$ \\
June & $67.95 \pm 4.42^{\mathrm{c}}$ & $88.3 \pm 9.1 \mathrm{~b}^{\mathrm{cd}}$ \\
\hline
\end{tabular}

*Within single columns, means with different letters are significantly different from one another $(\mathrm{P}<0.05)$.

Clams collected in December presented the lowest length shell $(62.38 \pm 3.84 \mathrm{~mm})$ and weight $(67.9 \pm 13.0 \mathrm{~g})$ values. Meanwhile, the highest length $(69.97 \pm 3.01 \mathrm{~mm})$ and weight
$(93.0 \pm 15.6 \mathrm{~g})$ were obtained in April 2014 and June 2013, respectively. Table 2 shows the bimonthly regression lines for the weightlength relationship.

There was a decrease in October that is coincident with the gonadic index (Fig. 1). The most continuous increment of weight of the standard individual was registered from December 2013 to February 2014.

Histology: No hermafroditism was found. The gonad developmental stages of M. squalida from June 2013 to June 2014, are shown in figure 2.

The gametogenic cycle was asynchronous with continuous spawning except for December. More than $50 \%$ of the population spawned in October, February and June 2014, while the lowest percentages of spawning were in August

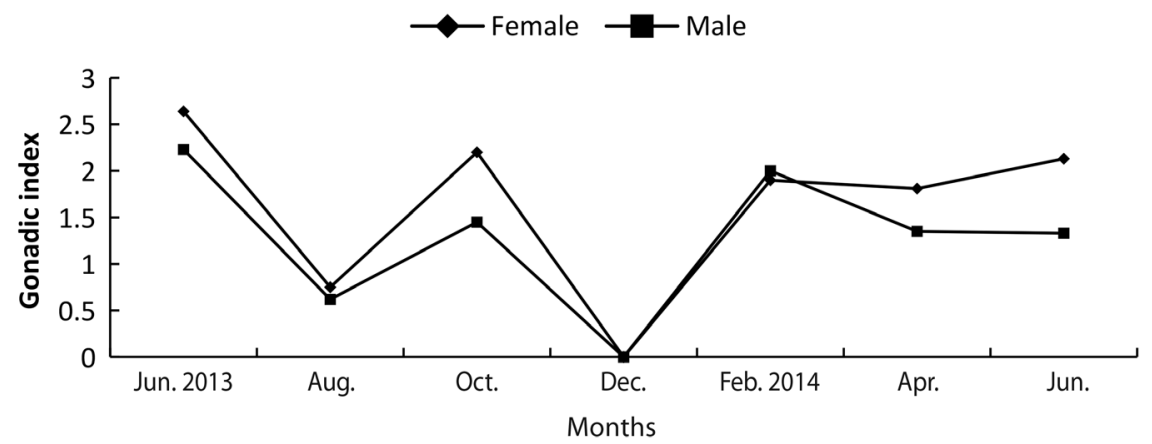

Fig. 1. Gonadic index of the callista clam M. squalida measured bimonthly at the collecting site in the Altata Bay, Sinaloa, Mexico.

TABLE 2

Bimonthly linear regression for weight-length relationship of the callista clam M. squalida collected in Altata Bay, Sinaloa, Mexico, from June 2013 to June 2014, after the logarithmic transformation of Ricker's function $\mathrm{W}=\mathrm{aL}^{\mathrm{b}}$ (Ricker, 1975)

\begin{tabular}{lcccccc} 
& $\mathrm{Lm}^{*}$ & Regression lines & $\mathrm{r}^{2}$ & $\mathrm{r}$ & $\mathrm{N}$ & $\mathrm{W}(\mathrm{L}=67.95 \mathrm{~mm})$ \\
June 2013 & $69.69 \pm 0.66$ & $y=0.2772 x+1.2986$ & 0.7957 & 0.8920 & 30 & 3.4620 \\
August & $68.50 \pm 0.81$ & $y=0.2878 x+1.281$ & 0.7394 & 0.8598 & 30 & 3.6162 \\
October & $68.93 \pm 0.70$ & $y=0.1958 x+1.4613$ & 0.539 & 0.7341 & 30 & 2.4603 \\
December & $62.38 \pm 0.70$ & $y=0.3065 x+1.235$ & 0.8254 & 0.9085 & 30 & 3.8874 \\
Feb. 2014 & $66.86 \pm 0.64$ & $y=0.3333 x+1.1885$ & 0.731 & 0.8549 & 30 & 4.4253 \\
April & $69.34 \pm 0.63$ & $y=0.306 x+1.2441$ & 0.7771 & 0.8815 & 30 & 3.9729 \\
June & $69.97 \pm 0.54$ & $y=0.2962 x+1.2688$ & 0.5321 & 0.7294 & 30 & 3.8234 \\
\hline
\end{tabular}

*Lm: average length; $\mathrm{r}^{2}$ : coefficient of determination; r: coefficient of correlation; N: number of observations; W $(\mathrm{L}=67.95$ $\mathrm{mm}$ ): weight of a standard individual of $67.95 \mathrm{~mm}$ long (= the mean size of the studied population). 

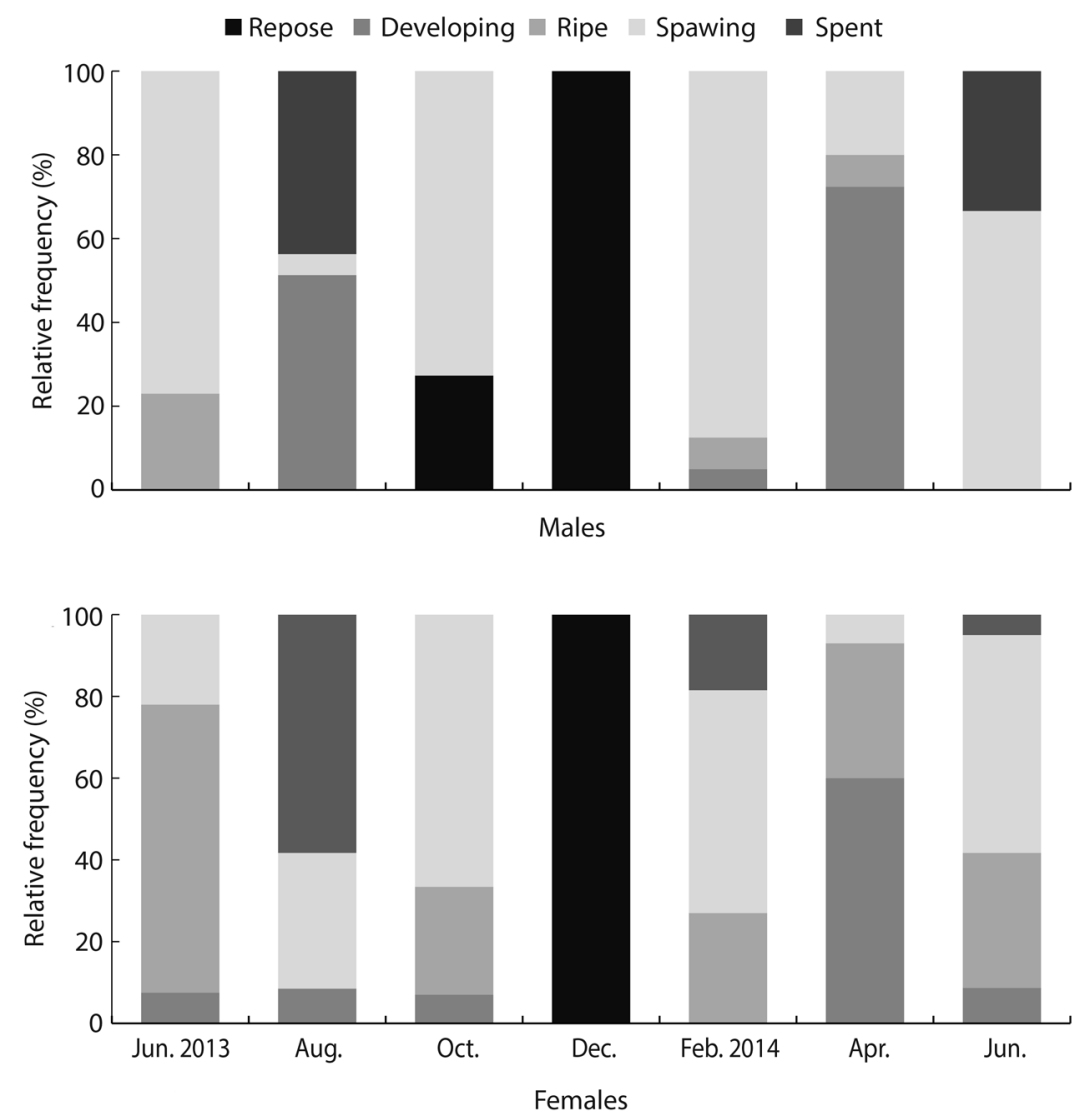

Fig. 2. Proportion of distinct gonad stages in M. squalida, sampled at the Altata Bay, Sinaloa, Mexico, from June 2013 to June 2014.

and April. An apparent resting period of all population was observed in December. The sex ratio was obtained for all animals except from those collected in December since sex of these clams was undifferentiated. Thus, sex-ratio (female:male) of the callista clam population $(\mathrm{N}=180)$ throughout all the sampling year was 1.08:1, from which $89(52 \%)$ were females and $82(48 \%)$ males. The result of the chi-square test $\left(\chi^{2}=5.72\right.$, d. f. $\left.=1, \mathrm{P}<0.05\right)$ indicated that the different proportion of sex obtained was not significant different than 1:1. Mean oocyte size was different $(\mathrm{P}<0.05)$ for all sampling months (Table 3).

The smallest oocyte size was observed in June $2014(34.60 \pm 5.8 \mu \mathrm{m})$, meanwhile, the largest size was observed in February (41.9 $\pm 6.8 \mu \mathrm{m})$. Overall oocyte size classes were ranged from $15 \mu \mathrm{m}$ in June 2013 to $59 \mu \mathrm{m}$ in February 2014. The number of oocytes showed significant differences $(\mathrm{P}<0.05)$ among the months, and fluctuated from $443.8 \pm 424.5$ found in February, to $1214.4 \pm 267.6$ counted in April. The stage of oocyte development varied from ripe in April, to spawning for the rest of months.

\section{DISCUSSION}

Previous studies regardless the reproduction of M. squalida reported a minimum shell size of $50 \mathrm{~mm}$ length (Villalejo-Fuerte et al., 1996, 2000) for adult bivalves in spawning stage. Due to the size range $(62.38-69.97 \mathrm{~mm}$ shell length) obtained in this work, it is possible 
TABLE 3

Size, number and stage of development of oocytes for the callista clam M. squalida collected in Altata Bay, Sinaloa, Mexico, from June 2013 to June 2014

\begin{tabular}{lcccccc} 
& Oocyte size $(\mu \mathrm{m})$ & Mean $\pm \mathrm{SD}(\mu \mathrm{m})$ & Number of oocytes & $f$ & $o$ & Stage of development \\
\multicolumn{1}{c}{ June 2013 } & $15-47$ & $35.4 \pm 5.3^{\mathrm{a} \mathrm{b}^{*}}$ & $980.4 \pm 189.0^{\mathrm{b}}$ & 3 & 150 & Spawning \\
August & $20-50$ & $36.4 \pm 5.9^{\mathrm{bc}}$ & $1076.2 \pm 559.8^{\mathrm{b}}$ & 3 & 150 & Spawning \\
October & $26-54$ & $39.9 \pm 6.2^{\mathrm{d}}$ & $516.4 \pm 210.7^{\mathrm{a}}$ & 3 & 150 & Spawning \\
December & - & - & - & - & - & - \\
February 2014 & $21-59$ & $41.9 \pm 6.8^{\mathrm{e}}$ & $443.8 \pm 424.5^{\mathrm{a}}$ & 3 & 150 & Spawning \\
April & $22-54$ & $37.7 \pm 6.5^{\mathrm{c}}$ & $1214.4 \pm 267.6^{\mathrm{b}}$ & 3 & 150 & Ripe \\
June & $21-52$ & $34.6 \pm 5.8^{\mathrm{a}}$ & $1128.0 \pm 284.7^{\mathrm{b}}$ & 3 & 150 & Spawning \\
\hline
\end{tabular}

Number of females $(f)$, number of measured of oocytes $(o)$.

$*$ Within the mean column, values with different letters are significantly different $(\mathrm{P}<0.05)$.

to state that collected callista clams were adults from one cohort in reproductive age. According to commercial fishery observations, the average size of chocolate clam specimens increases with water depth. Our bivalves were collected at a mean water depth and transparency of $0.97 \pm 0.3 \mathrm{~m}$. Schweers et al. (2006) reported that individuals larger than $135 \mathrm{~mm}$ could be found in water depths deeper than $10 \mathrm{~m}$. The size distribution of clams in sand bottom from intertidal to progressively further down areas, seems to be related to behavior changes which make that larger clams might move deeper, where conditions for spawning are better (Bally, 1983), and this could be the case of the clam population sampled at the subtidal sand area in Altata Bay, Sinaloa.

Male and female gonads of the callista clam developed and underwent asynchronous along the sampling period. With exception of December, clams spawned throughout the year with peaks in October and February. The higher decrease in weight, reflected by the gonadic index, shown the lowest value after the spawning of October which coincides with a high percentage of population in spawning. A clear repose or resting period was observed in December, whereas gonadic index values were higher in October. Same reproductive pattern of this clam species from Northwestern Mexico populations was observed by ArellanoMartínez et al. (2006). Although the histological sample of $M$. squalida collected in February displayed a high percentage of organisms in spawning, did not show any loss in weight, which seems to indicate that most of the clams released a low amount of gametes (Tirado, Salas, \& Márquez, 2003). Microscopical measurements for the oocytes collected in February, obtained the lower amount of oocytes, confirming a partial emission of gametes.

The above data pointed out that the most important spawning period (maximum amount of released gametes) for the clam population from Altata Bay, Sinaloa, was October-November. Our findings reported here differed from other studies. Working with the same species, Villalejo-Fuerte et al. (2000) mentioned that with exception of April, September and October, populations of the chocolate clam from Juncalito Bay, Baja California Sur, spawned throughout the whole study period. Meanwhile, Arellano-Martínez et al. (2006) concluded that M. squalida from Ojo de Liebre lagoon, Baja California Sur, spawned from February to August. The differences among works might be associated to the environmental parameters (food availability and temperature) at each locality. To this respect, Baqueiro and Aldana (2000) stated that some mollusk species display different spawning patterns linked with the environmental conditions of their habitat.

A positive relationship between temperature and reproductive activity for some bivalves has been documented (Villalejo-Fuerte et al., 1996; Corte, Yokohama, \& Amaral, 2014), 
in which the rise in water temperature may stimulate gonad ripening. In this study, the reproductive activity of $M$. squalida (measured through the variation in the mean number and diameter of oocytes and the gonad index) was not significantly and positively correlated with water temperature differing with those results reported by Arellano-Martínez et al. (2006) for the same species. Previous information on reproduction of wild populations of $M$. squalida at different mexican coastal localities (Villalejo-Fuerte et al., 1996, 2000; Singh et al., 1991; Baqueiro \& Stuardo, 1977) differed substantially to each other, and with respect to the results obtained in this study; the most obvious difference is focused on the temporality of the reproductive cycle, which could be related to the water temperature (ArellanoMartínez et al., 2006). On other hand, it is interesting to observe that the peak of spawning of M. squalida occur when the $\mathrm{Cl} a$ concentration increased, suggesting that as well as with temperature, there was some relationship between levels of phytoplankton and spawning, as mentioned by Schweers et al. (2006). The resting period observed in December for the total clam population coincided with the decreasing of water temperature. MacDonald and Thompson (1985) mentioned that seasonal differences in gonad development in bivalves, can be attributed to environmental fluctuations. Same conclusions were found by ArellanoMartínez et al. (2006) and Villalejo-Fuerte et al. (2000) working with the same clam species in the central part of the Gulf of California.

The sex ratio in the population studied did not deviate significantly from the proportion of $1: 1$, which coincides with reports for the same clam species in other mexican coastal localities (Baqueiro \& Stuardo, 1977; Villalejo-Fuerte et al., 1996, 2000; Arellano-Martínez et al., 2006), indicating that sex ratio is a speciesspecific characteristic. Therefore, it can be inferred that mortality (by catch or naturally) is not dependent on sex dimorphism. The asynchronic gametogenic cycle in the callista clam population from Altata Bay, Sinaloa, Mexico, is partially reflected by the coexistence of several stages of development in the same gonad. Such gonad condition has been found in many bivalves from temperate areas (Tirado \& Salas, 1998, 1999).

Although the total capture of M. squalida is relatively low according to official statistical data, they are obtained from three coastal localities (Los Mochis, Navolato and Guasave municipalities) in the state of Sinaloa, representing an important fishery in the local economy. Since there is a lack of information on the biology of this species at the Sinaloa' state, it is not possible to conclude on the evolution of its average size in the Altata population. However, the reduction of the volume of catches suggests an overexploitation of this resource, and highlights the implementation need of a closed season. According to the data of this study, the closed season should be established from October to November, when the most intense release of gametes occurs, observed also with the high loss of weight together with the high percentage of the population in spawning activity.

\section{ACKNOWLEDGMENTS}

The project was supported by the Instituto Politécnico Nacional (IPN) through the Secretaría de Investigación y Posgrado (SIP), with the project number SIP-20120088. We are grateful to all fishermen from the Altata Fishery Cooperative for collecting the clams, and wish to thank Juan Antonio Hernández Sepúlveda, María Isabel Sotelo González and Ely Sara López Álvarez for helping in the laboratory work.

\section{RESUMEN}

Reproducción de la almeja callista Megapitaria squalida (Bivalvia: Veneridae) en el sureste del Golfo de California, México. El ciclo reproductivo de los bivalvos varía de acuerdo a las condiciones ambientales de cada lugar, y representa información importante para su conservación. Se estudió el ciclo reproductivo de la almeja Megapitaria squalida utilizando cortes histológicos de la gónada y cambios en el número y tamaño de los oocitos, en el sur del Golfo de California (Bahía Altata, Sinaloa, México), 
desde junio 2013 a junio 2014. El análisis histológico de las gónadas, mostró eventos de desove todo el año con dos picos: el primero fue registrado en octubre acompañado con un fuerte decremento en peso de los animales; el segundo en febrero caracterizado por un alto porcentaje de desove en la población. Se observó un periodo de reposo en diciembre. La proporción sexual (hembras:machos) de la población de almejas fue 1.08:1 $\left(\chi^{2}=5.72\right.$, g.1. $=1, \mathrm{P}<$ $0.05)$. El número y tamaño promedio de los oocitos mostró diferencias $(\mathrm{P}<0.05)$ entre los muestreos mensuales, y fluctuaron de $34.6 \pm 5.8 \mu \mathrm{m}$ en junio 2014 a $41.9 \pm 6.8 \mu \mathrm{m}$ en febrero 2014, y de $443.8 \pm 424.5$ en febrero 2014, a 1 $214.4 \pm 267.6$ en abril 2014. Se propone una temporada de veda desde octubre a noviembre, ya que en estos meses la liberación de gametos por la población fue más intensa.

Palabras clave: índice gonádico, Megapitaria squali$d a$, desarrollo de oocitos, época de desove, manejo de captura, conservación.

\section{REFERENCES}

Arellano-Martínez, A., Quiñones-Arreola, M. F., Ceballos-Vázquez, B. P., \& Villalejo-Fuerte, M. (2006). Reproductive pattern of the squalid callista Megapitaria squalida from northwestern Mexico. Journal of Shellfish Research, 25(3), 849-855. http://doi. org/10.2983/0730-8000(2006)25

Bally, R. (1983). Intertidal zonation on sandy beaches of the west coast of South Africa. Cahiers de Biologie Marine, 24, 85-103.

Baqueiro, C. E., \& Stuardo, J. (1977). Observaciones sobre la biología, ecología y explotación de Megapitaria aurantiaca (Sow, 1831), M. squalida (Sow, 1835) y Dosinia ponderosa (Gray, 1838) (Bivalvia: Veneridae) de la Bahía de Zihuatanejo e Isla de Ixtapa, Guerrero, México. Anales del Instituto de Ciencias Marinas y Limnología. Universidad Nacional Autónoma de México, 4, 161-208.

Baqueiro, C. E., \& Aldana, D. A. (2000). A review of reproductive patterns of bivalve mollusks from Mexico. Bulletin of Marine Sciences, 66, 13-27.

Baqueiro-Cárdenas, E., Masso, J. A., \& Guajardo, H. (1982). Distribución y abundancia de moluscos de importancia comercial en Baja California Sur. Instituto Nacional de la Pesca, México. Serie de Divulgación, 11, 32.

Castro-Ortíz, J. L., Tripp-Quezada, A., \& Anguas-Velez, B. (1992). Crecimiento de la almeja chocolata Megapitaria squalida (Sowerby, 1835) en Bahía Concepción, Baja California Sur, México. Investigaciones Marinas CICIMAR, 7, 1-7.

Corte, G. N., Yokohama, L. Q., \& Amaral, A. C. Z. (2014) An attempt to extend the habitat harshness hypothesis to tidal flats: A case study of Anomalocardia brasiliana (Bivalvia: Veneridae) reproductive biology. Estuary, Coastal and Shelf Science, 150, 136-141. http://doi.org/10.1016/j.ecss.2013.12.007

Cruz, A. R., \& Villalobos, C. R. (1993). Shell length at sexual maturity and spawning cycle of mussel Mytella guyanesis (Bivalvia: Mytillidae) from Costa Rica. Revista de Biología Tropical, 41, 89-92.

Gaxiola-Castro, L. J. (2003). Atlas de los ecosistemas de Sinaloa. Sinaloa, México: Edit. El Colegio de Sinaloa.

Humason, G. L. 1979. Animal tissue techniques (4 ${ }^{\text {th }}$. ed.). San Francisco, USA: W. H. Freeman and Co.

Jeffrey, S. W., \& Humphrey, G. T. (1975). New spectrophotometric equation for determining chlorophylls $a, b, c^{1}$ and $c^{2}$ in higher plants, algae and natural phytoplankton. Biochemistry and Physiology. Pflanzen, 167, 191-194.

Keen, A. M. (1971). Seashells of Tropical West America. Marine Mollusks from Baja California to Peru. California, USA: Stanford University Press.

Laruelle, F., Guillou, J., \& Paulet, Y. M. (1994). Reproductive pattern of the clams, Ruditapes decussatus and Ruditapes philippinarum on intertidal flats in Brittany. Journal of Marine Biology Association UK, 172, 69-96. http://doi.org/10.1017/S0025315400039382

López-Rocha, J. A., Ceballos-Vázquez, B. P., GarcíaDomínguez, F. A., Arellano-Martínez, M., Villalejo-Fuerte, M., \& Romo-Piñera, A. K. (2010). La pesquería de la almeja chocolate Megapitaria squalida (Bivalvia: Veneridae) en Baja California Sur, México. Hidrobiológica, 20(3), 230-237.

MacDonald, B. A., \& Thompson, R. J. (1985). Influence of temperature and food availability on the ecological energetic of the giant scallop Placopecten magellanicus. II Reproductive output and total production. Marine Ecology Progressive Series, 25, 295-303.

Quiñones-Arreola, M. F. (2003). Comparación del patrón reproductivo de Megapitaria squalida (Sowerby, 1835) en la Laguna de Ojo de Liebre, Océano Pacifico, y Bahía Juncalito, Golfo de California, B. C. S., México (Tesis Maestría). CICIMAR, Instituto Politécnico Nacional, La Paz, Baja California Sur, México. Retrieved from http://www.biblioteca.cicimar.ipn. $\mathrm{mx} /$ oacis/Medios/tesis/quinonesa1.pdf

Ricker, W. (1975). Computation and interpretation of biological statistics of fish population. Bulletin of Fisheries Research Board Canadian, 191, 1-382.

Rodríguez, S., Quintana, R., Lamas, L., Ayensa, G., Velasco, F. J., \& Pascual, C. (1993). Etude comparative du cycle gamétogénique et composition biochimique de Tapes decussatus et Ruditapes philippinarum dans la Ría de Muros y Noya. In G. Barnab \& P. Kestemont (Eds.), Production, Environment and Quality Bordeaux Aquaculture 92'. European Aquaculture 
Society (Special Publication No. 18, pp. 503-511). Ghent: Belgium.

Ruiz, C. J. A., Medina, G. G., Macías, C. J., Silva, S. M., \& Díaz, P. J. (2005). Estadísticas climatológicas básicas del estado de Sinaloa (Periodo 1961-2003) (Libro Técnico Núm. 2). Cd. Obregón, Sonora, México: INIFAP-CIRNO.

Ruíz-García, J. A., Guevara-Ponce, J., Saucedo-Barrón, C. J., Góngora-Gómez, A. M., Domínguez-Orozco, A. L., Soto-Cabrera, G., Aguilar-Pérez, L. M., \& Alduenda-Rojas, L. A. (2013). Programa de repoblación de la almeja chocolata en Bahía de AltataEnsenada de Pabellones, Navolato, Sinaloa, México. Ciclo reproductivo, desarrollo larval, fijación de semilla de almeja chocolata (Megapitaria squalida) en el refugio pesquero de Bahía Altata, Navolato, Sinaloa. Sinaloa, México: ISAPESCA, SAGARPA, CIIDIR-SINALOA.

SAGARPA (2015). Consulta específica por producción (gob.mx). Recuperado de http://www.conapesca. sagarpa.gob.mx/wb/cona/

Schweers, T., Wolff, M., Koch, V., \& Sinsel-Duarte, F. (2006). Population dynamics of Megapitaria squalida (Bivalvia: Veneridae) at Magdalena Bay, Baja California, Sur, Mexico. Revista de Biología Tropical, 54, 1003-1017. http://doi.org/10.15517/rbt. v54i3.13973

Singh, C. J., Vélez, J. A., \& Fajardo, M. C. (1991). Estudio poblacional de la almeja chocolata Megapitaria squalida (Sowerby, 1835) en Punta Coyote, Bahía de La Paz, B. C. S., México. Ciencia Pesquera. Instituto Nacional de la Pesca, México, 8, 1-22.

Strickland J. D., \& Parsons T. R. (1972). A practical handbook for the sea water analysis. Ottawa, Canada: Bulletin. Fisheries Research Board of Canada.
Tirado, C., \& Salas, C. (1998). Reproduction and fecundity of Donax trunculus L., 1758 (Bivalvia: Donacidae) in the littoral of Málaga (southern Spain). Journal of Shellfish Research, 17, 169-176.

Tirado, C., \& Salas, C. (1999). Reproduction of Donax ventusus Poli 1795, Donax semistriatus Poli 1795 and intermediate morphotypes (Bivalvia: Donacidae) in the littoral of Málaga (southern Spain) P. S. Z. N. Marine Ecology, 20, 111-130.

Tirado, C., Salas, C., \& Márquez, I. (2003). Reproduction of Venus verrucosa L., 1785 (Bivalvia: Veneridae) in the littoral of Málaga (southern Spain). Fisheries Research, 63, 437-445. http://doi.org/10.1016/ S0165-7836(03)00106-1

Vázquez-Hurtado, M., Manzano-Sarabia, M., \& OrtegaRubio, A. (2011). Relación entre las capturas de Megapitaria squalida (Bivalvia: Veneridae) y la temperatura superficial del mar de la Bahía de la Paz, Baja California Sur, México. Revista de Biología Tropical, 59(1), 151-157.

Villalejo-Fuerte, M., García-Melgar, G., Ochoa-Báez, R. I., \& García-Gasca, A. (1996). Ciclo reproductivo de Megapitaria squalida (Sowerby, 1985) (Bivalvia: Veneridae) en Bahía Concepción, B. C. S., México (Boletín No. 4). Santa Fé de Bogotá, Colombia: Instituto Nacional de la Pesca y Acuacultura.

Villalejo-Fuerte, M., Arellano-Martínez, M., CeballosVázquez, B. P., \& García-Domínguez, F. (2000). Ciclo reproductivo de la almeja chocolata Megapitaria squalida (Sowerby, 1835) (Bivalvia: Veneridae) en Bahía Juncalito, Golfo de California, México. Hidrobiológica, 10, 165-168.

Zar, J. H. (1996). Bioestatistical analysis (3rd. Ed.). New Jersey, USA: Englewood Cliffs, Prentince Hall. 